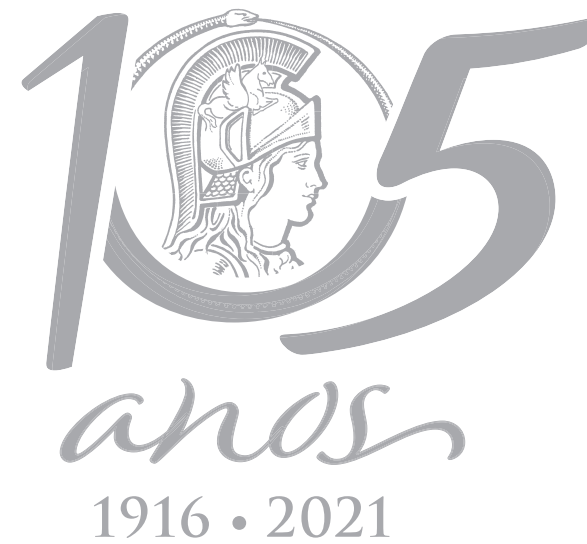

$1916 \cdot 2021$

\title{
ECOSYSTEMS
}

\section{Anurans trophic dynamic and guild structure in tropical dry forests of the Caribbean region of Colombia}

\author{
ARGELINA BLANCO-TORRES, MARTA DURÉ \& MARÍA ARGENIS BONILLA
}

\begin{abstract}
Studies on the exploitation of trophic resources allow to establish interactions between predators and predator-prey, and this dynamic can present fluctuations over time and space. We analysed stomach contents of 19 anuran species from tropical dry forests of Colombia, quantified the overlap between species and identified anuran trophic guilds. Most of the species were generalists in diet (89.5\%), some with strong prey dominance and only two species were classified as specialists. Two anurans guilds were identified according to diet structure and habitat use: "ground foraging anurans, consuming Formicidae and Isoptera" and "arboreal 'sit-and-wait' predators, primarily consuming arachnids". A considerable number of species did not clearly group in community trophic structure analysis. The level of taxonomic resolution with that preys are worked affects analysis of trophic niches segregation when analyzing regional and local patterns. Anuran species of tropical dry forest in the Colombian Caribbean display trophic resources partitioning at the level of species and/or morphospecies, as a mechanism of coexistence.
\end{abstract}

Key words: Amphibia, Neotropical lowlands, Trophic overlap, Prey taxonomic. resolution.

\section{INTRODUCTION}

Studies on the dynamics of resources use have been a subject of interest in ecology, giving rise to numerous concepts related to interspecific associations. Numerous studies report the relationship that exists between environmental and spatial variability with trophic ecology (Almeida et al. 2019, Ceron et al. 2019, Le et al. 2019) therefore, any study that attempts to understand the trophic dynamics of the species that inhabit it must include in its analysis both the spatial and temporal fluctuations of their diets as the level of trophic overlap between taxa, since the diet is mediated by both, habitat type and seasonality; according to this, each type of prey can vary in quantity affecting the overlap (Vitt \& Caldwell 2014, Almeida et al. 2019, Le et al. 2019, Michelin et al. 2020).

The guild concept is linked to the study of trophic relationships between species, and is defined as a group of species that use the same resource in a similar manner, that may be exploited in the same way using similar structures and capturing equivalent amounts of resources via active or passive acquisition (Root 1967, Hawkins \& MacMahon 1989, Simberloff \& Dayan 1991). The guild concept is referring to species that use a resource in a similar way, and might not be equivalent to the function that this group may have in the system, but it is the first approach to this explanation of functionality. From studies on this topic, it is known that guilds are structured according to available resources 
used and often affect the environmental changes on their structural dynamics (e.g., Morin 1983, Williams \& Hero 1998, Parker et al. 2001, Adams 2007).

Guilds and management strategies applied to environmental conservation are closely associated (Martinez Ramos 2008). Thus, the ability to define that species exploit each kind of resource, how they do so, and how they can be grouped according to resource use, facilitates the assessment of diversity in ecosystems facing habitat modification. Habitat modification alters available resources and affects natural community structure. Therefore, it can have implications on important aspects such as productivity (Simberloff \& Dayan 1991, Bengtsson 1998, Brussaard 1998, Briceño-Méndez et al. 2017). In amphibians, as in other animal groups, guilds have been identified based on food consumption patterns.

One of the most relevant aspects of defining trophical guilds is how different species exploit their resources. Because of this, the identification of prey is essential to assign each species to a guild. Tropical forests present a high structural complexity and a large diversity of arthropod species (Rangel et al. 1995, Pizano \& García 2014) which are the main prey of amphibians. This diversity is reflected in the diet of the amphibians that inhabit this region. Therefore, when analyzing regional patterns of diet variability, it is commonly to analyze prey at the order level, faciliting the comparison with other studies and between sites within the same region. Taking into account the high diversity of insects in tropical forests, no overlap is observed at higher taxonomic resolution levels such as family or morphospecies (García-Robledo et al. 2020). These levels can be used to analyze diet variability locally and correctly identify the segregation of trophic niche, especially when the general pattern indicates overlap (Piatti \& Souza
2011, Fonseca-Pérez et al. 2017). The coexistence of species that have overlapping diets may be explained in part by the high abundance of the resource and by the segregation of prey at higher taxonomic resolution levels.

Lowland amphibians in northern Colombia are immersed in the distribution area of the tropical dry forest, which in the Colombian Caribbean region (Vargas-Salinas et al. 2019). This region is limited to a few isolated fragments in the lowlands immersed in an anthropogenic matrix, which usually constitutes a mosaic of economic activities (e.g. livestock, agriculture, infrastructure, mining) (Pizano \& García 2014, Vargas-Salinas 2019), developed without planning, producing a decrease of this type of forest to only $8 \%$ of its original coverage (Pizano \& García 2014). The study of trophic patterns of amphibians is not only a tool to establish how they are associated, but also provide important elements to understand how ecosystems work and its structure (Ranvestel et al. 2004, Ceron et al. 2019, Le et al. 2019). These works, based on anurans, one of the groups of vertebrates with the highest rates of species loss worldwide (Stuart et al. 2008), also allow to analyze how the transfer of energy occurs both between aquatic and terrestrial habitats and among different trophic levels (Ranvestel et al. 2004, Wells 2007, vitt \& Caldwell 2014, Le et al. 2019). In addition, they provide tools for the proper management and conservation of species, communities and ecosystems, by analyzing the vulnerability of species in relation to the degree of specialization of their diets, environmental changes or variations in patterns of ecological interactions (Duré et al. 2009, Clavel et al. 2011, Le et al. 2019). Consequently, the identification of trophic anuran guilds in the Colombian tropical dry forest, a habitat that has lost most of its natural condition, contribute to the purpose 
of designing viable strategies that help the recovery of this ecosystem.

In this work, we explore regional trophic patterns (prey consumption, diet overlap and trophic guilds) of a group of lowland anuran species from the tropical dry forests of the Colombian Caribbean region. In order to characterize their trophic dynamics and the partition of food resources, we analyze both spatial (site) and temporal (season) diet variations for this lowland region.

\section{MATERIALS AND METHODS}

\section{Study area}

The study site is located in the lowlands of the Colombian Caribbean (3-206 m altitude range), which exhibit the highest percentage of original coverage of tropical dry forest in the country (Pizano \& García 2014). The monthly temperature range for the study area is 26.6 to $30.1^{\circ} \mathrm{C}$. The tropical dry forest has a maximum rainfall of 2,000 $\mathrm{mm}$ per year with a marked seasonality determined by rainfall: a dry season (DecemberApril) and rainy season (May-November), with the highest rainfall occurring in the months of August and November (Pizano \& García 2014).

Six sites were selected by the presence of primary tropical dry forest fragments greater than 80 ha. Sites are surrounded by human activities of extensive livestock and little and medium extension of transient crops for food, as follows: Site $1\left(11^{\circ} 5^{\prime} \mathrm{N}-2^{\circ} 38^{\prime} \mathrm{W}\right)$ at $79 \mathrm{~m}$ altitude, with the presence of open-cast coal mining; Site $2\left(10^{\circ} 4^{\prime} \mathrm{N}-74^{\circ} 1^{\prime} \mathrm{W}\right)$ at $82 \mathrm{~m}$ altitude, with the presence of oil palm (Elaeis guineensis) cultivation; Site $3\left(10^{\circ} 35^{\prime} \mathrm{N}-74^{\circ} 8^{\prime} \mathrm{W}\right)$ at $197 \mathrm{~m}$ altitude with the presence of extensive livestock and little extension of transient crops for food; Site $4\left(10^{\circ} 44^{\prime} \mathrm{N}-75^{\circ} 5^{\prime} \mathrm{W}\right)$ at $206 \mathrm{~m}$ altitude, with the presence of extensive livestock and little and medium extension of transient crops for food; Site $5\left(10^{\circ} 37^{\prime} \mathrm{N}-75^{\circ} 14^{\prime} \mathrm{W}\right)$ at $34 \mathrm{~m}$ altitude, with the presence of extensive livestock and forest conservation project; site $6\left(8^{\circ} 47^{\prime} \mathrm{N}\right.$ $-76^{\circ} 19^{\prime} \mathrm{W}$ ) at $120 \mathrm{~m}$ altitude, with the presence of extensive livestock (Fig. 1).The assembly of amphibians of each site is not connected to any of the other sites (separated by at least 100 linear kilometres).

\section{Field sampling}

Field work was conducted during the dry season between February and March, the early rainy season or "minor rains" between May and June, and during the late rainy season or "heavy rains" between October and November in 2010. Two persons performed sampling sessions of five nights for each study site, between 19:00 and 23:00 hours; each site was sampled three times, one per climate season (sampling effort: 120 person-hours per site).

An active search for frogs by visual encounter surveys was made (Crump \& Scott 1994), both in the horizontal plane at ground I water level, and in the vertical strata, at different vegetation heights $(0 \sim 15 \mathrm{~m})$. Anurans (subadult and adults) were manually collected (Table I). To quantify the use of habitats, the number of individuals per species detected was recorded through every night surveys (visual encounter) by approximately one-hour duration. These habitats were identified and classified in all sites as: 1) rangelands, which were areas dedicated to livestock, especially cattle; 2) crops, areas dedicated to transient or perennial crops on a small or large scale; 3 ) lotic water-bodies in anthropic matrix (Al-Lotic), such as streams and small rivers that are within the anthropic matrix; 4) lentic water-bodies in anthropic matrix (Al-Lentic), generally artificial bodies of water constructed as reservoirs for livestock, agriculture and domestic use, in addition to temporary or permanent natural 


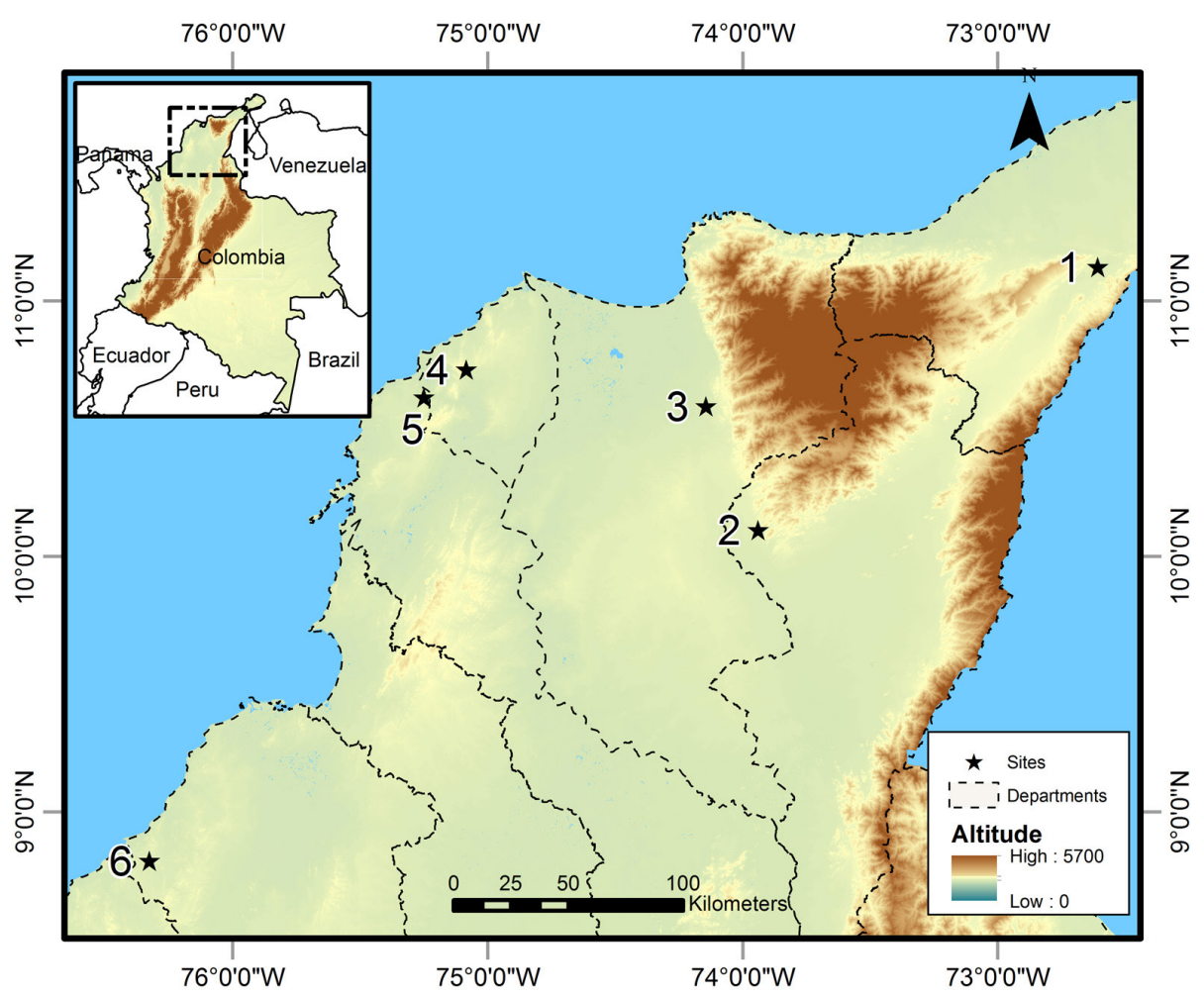

Figure 1. Study sites in tropical dry forest in northern Colombia. 1= Site 1 (Department: La Guajira), 2= Site 2 (Department: Cesar); 3: Site 3 (Department: Magdalena), 4= Site 4 (Department: Atlántico), $5=$ Site 5 (Department: Bolivar), $6=$ Site 6 (Department: Córdoba).

puddles formed by rains; in forests= (5) F-edge, the adjacent area or edge of the forest that lies between the anthropic matrix, and finally, 6) the interior of forest (Forest), referring to areas sampled inside the forest fragments. The surveys were conducted from the centre to the edges of each habitat type.

\section{Laboratory analysis}

Individuals were measured (snout vent lengthSVL, jaw width- JW) using a digital caliper with a $0.01 \mathrm{~mm}$ accuracy, euthanized and fixed in the field after each night of sampling according protocols suggested in Angulo et al. (2006). Then, in the laboratory they were dissected (vouchers deposited in the museum of Universidad del Atlántico) and stomach contents were extracted. Samples were preserved in individual vials in $70 \%$ ethanol solution. Each extracted content was placed in a Petri dish, where it was separated by differentiable items (adults and larvae), measured and classified to the lowest possible taxonomic category (species or morphospecies). In this way, for the data analysis, we were able to determine all the prey samples to species and morphospecies, through taxonomic keys (e.g. Fernandez 2003, Triplehorn \& Johnson 2005, Wolff 2006) and consulting specialists for each group.

\section{Data analysis}

The preys were grouped into three levels of taxonomic classification in order to explore the variability in the diet on a spatial and temporal scale and to test whether the patterns obtained are repeated at each level of classification. We use Order level to detect general patterns in food consumption (especially overlap and guild identification) and obtain results comparable to other studies. We also classified preys at the family and species/morphospecies level to observe consumption behavior at a higher level 
Table I. Dietary characteristics of the anuran species studied in tropical dry forests of Caribbean Colombia. $n$ = Number of stomach. JW-PV= Relationship between predator and prey size using jaw width and prey volume. Amplitude $=$ Amplitude of Levins index, the standardized amplitude value is shown in brackets; Diversity = Diversity of trophic niche (Shannon index); Foraging Mode = SW: Sit-and-wait, AF: Active forager; Diet Type = GEN: Generalist, ESP: Specialist, GEN (D): Generalist with predominancia; Habit = T: Terrestrial, A: Arboreal; Diet composition = F: prey group or order with more frequent occurrence (highest occurrence value), Abd: prey group or order with greater number of individuals, Vol: prey group or order with greater volume ingested; Hymenoptera, Is = Isoptera, Iso = Isopoda, L = Larvae, Lep = Lepidoptera, Ort = Orthoptera. Data taken from this research, BlancoTorres et al. (2019) and Blanco-Torres et al. (2020).

\begin{tabular}{|c|c|c|c|c|c|c|c|c|c|c|c|}
\hline \multirow{2}{*}{ No } & \multirow{2}{*}{ Family/Species } & \multirow{2}{*}{$n$} & \multirow{2}{*}{$\begin{array}{c}J W-P V \\
r_{\text {obs }}\left(p_{\text {value }}\right)\end{array}$} & \multirow{2}{*}{$\begin{array}{l}\text { Levins } \\
\text { (Standard) }\end{array}$} & \multirow{2}{*}{$\begin{array}{c}\text { Shannon } \\
\text { Index }\end{array}$} & \multirow{2}{*}{$\begin{array}{c}\text { Foraging } \\
\text { mode }\end{array}$} & \multirow{2}{*}{$\begin{array}{l}\text { Diet } \\
\text { type }\end{array}$} & \multirow{2}{*}{ Habit } & \multicolumn{3}{|c|}{ Diet composition } \\
\hline & & & & & & & & & $\mathbf{F}$ & Abd & Vol \\
\hline \multicolumn{12}{|c|}{ BUFONIDAE } \\
\hline 1 & Rhinella humboldti & 85 & $\begin{array}{c}0.34 \\
(<0.0001)\end{array}$ & $1.54(0.05)$ & 0.81 & $A F$ & GEN(D) & $\mathrm{T}$ & $\begin{array}{l}\text { Hym } \\
\text { (For) }\end{array}$ & $\begin{array}{l}\text { Hym } \\
\text { (For) }\end{array}$ & Col \\
\hline 2 & Rhinella marina & 74 & $\begin{array}{c}0.43 \\
(<0.0001)\end{array}$ & $2.43(0.07)$ & 1.19 & $A F$ & GEN(D) & $\mathrm{T}$ & $\begin{array}{l}\text { Hym } \\
\text { (For) }\end{array}$ & $\begin{array}{l}\text { Hym } \\
\text { (For) }\end{array}$ & $\begin{array}{l}\text { Hym } \\
\text { (For) }\end{array}$ \\
\hline \multicolumn{12}{|c|}{ CRAUGASTORIDAE } \\
\hline 3 & Craugastor raniformis & 21 & $0.24(0.51)$ & $6.15(0.73)$ & 1.93 & SW & GEN & $\mathrm{T}$ & Dipl-Ar & Dipl & Ort \\
\hline \multicolumn{12}{|c|}{ HYLIDAE } \\
\hline 4 & $\begin{array}{l}\text { Dendropsophus } \\
\text { microcephalus }\end{array}$ & 99 & $0.10(0.23)$ & $4.19(0.39)$ & 1.79 & SW & GEN & A & $\operatorname{Ar}$ & $\operatorname{Ar}$ & Lep \\
\hline 4 & Boana pugnax & 98 & $0.32(0.003)$ & $6.45(0.54)$ & 2.02 & SW & GEN & A & Col & Col & Ort \\
\hline 6 & Scarthyla vigilans & 50 & $-0.17(0.32)$ & $3.35(0.58)$ & 1.38 & SW & GEN(D) & A & Hem & Hem & Hem \\
\hline 7 & Scinax rostratus & 38 & $-0.28(0.26)$ & $7.14(0.87)$ & 2.03 & SW & GEN & A & $A C$ & $A C$ & Ort \\
\hline 8 & Scinax ruber & 45 & $-0.81(0.02)$ & $4.59(0.63)$ & 1.82 & SW & GEN & A & Hem & Hem & Ort \\
\hline 9 & $\begin{array}{c}\text { Trachycephalus } \\
\text { typhonius }\end{array}$ & 16 & $-0.02(0.55)$ & $3.02(0.4)$ & 1.39 & SW & GEN & A & Lep (L) & Lep (L) & $\begin{array}{l}\text { Lep } \\
(\mathrm{L})\end{array}$ \\
\hline \multicolumn{12}{|c|}{ PHYLLOMEDUSIDAE } \\
\hline 10 & Phyllomedusa venusta & 28 & $0.04(0.57)$ & $4.92(0.65)$ & 1.75 & SW & GEN & A & Ort & $A c$ & Ort \\
\hline \multicolumn{12}{|c|}{ LEPTODACTYLIDAE } \\
\hline 11 & Engystomops pustulosus & 75 & $0.47(0.019$ & $1.88(0.06)$ & 0.96 & AF & GEN(D) & $\mathrm{T}$ & Is & IS & Is \\
\hline 12 & Pleurodema brachyops & 95 & $0.26(0.004)$ & $3.83(0.2)$ & 1.66 & $A F$ & GEN & $\mathrm{T}$ & $\begin{array}{l}\text { Hym } \\
\text { (For) }\end{array}$ & $\begin{array}{l}\text { Hym } \\
\text { (For) }\end{array}$ & L.Col \\
\hline 13 & Pseudopaludicola pusilla & 80 & $-0.10(0.26)$ & $4.93(0.3)$ & 1.98 & AF & GEN & $\mathrm{T}$ & Col & Dip & Hem \\
\hline 14 & Leptodactylus insularum & 83 & $0.22(0.03)$ & $5.01(0.22)$ & 2.06 & AF & GEN & $\mathrm{T}$ & Col & Col & Col \\
\hline 15 & Leptodactylus fragilis & 93 & $0.44(0.001)$ & $7.12(0.47)$ & 2.17 & AF & GEN & $\mathrm{T}$ & Col & Col-Is & Ort \\
\hline 16 & Leptodactylus fuscus & 47 & $0.19(0.20)$ & $5.58(0.4)$ & 2.04 & SW & GEN & $\mathrm{T}$ & Col & $\begin{array}{l}\text { Hym } \\
\text { (For) }\end{array}$ & $\mathrm{Col}$ \\
\hline 17 & $\begin{array}{l}\text { Leptodactylus } \\
\text { poecilochilus }\end{array}$ & 40 & $0.32(0.06)$ & $7.72(0.67)$ & 2.15 & $\mathrm{AF}$ & GEN & $\mathrm{T}$ & Col & Iso & Col \\
\hline \multicolumn{12}{|c|}{ MICROHYLIDAE } \\
\hline 18 & Elachistocleis pearsei & 5 & $-0.58(0.17)$ & $1.04(0.4)$ & 0.04 & $A F$ & ESP & $\mathrm{T}$ & $\begin{array}{l}\text { Hym } \\
\text { (For) }\end{array}$ & $\begin{array}{l}\text { Hym } \\
\text { (For) }\end{array}$ & $\begin{array}{l}\text { Hym } \\
\text { (For) }\end{array}$ \\
\hline 19 & $\begin{array}{c}\text { Elachistocleis } \\
\text { panamensis }\end{array}$ & 9 & $-0.75(0.06)$ & $1.98(0.98)$ & 0.69 & $A F$ & ESP & $\mathrm{T}$ & Is & IS & IS \\
\hline
\end{tabular}


of taxonomic resolution. We use morphospecies because in these tropical forests the diversity of invertebrates (especially insects) is very high and most of the species are indescribed (GarcíaRobledo et al. 2020).

The number and volume of prey per stomach were determined for each type of food item. The volume $\left(\mathrm{mm}^{3}\right)$ of each type of prey per stomach was calculated using the ellipsoid formula (Dunham 1983). For incomplete prey items, the size of a complete specimen of the same prey was used. The frequency of occurrence of each prey species was calculated as the number of stomachs in which each food item was found for each anuran species. Prey diversity was calculated using the Shannon-H 'index (Ln transformed) (Magurran 2004). The amplitude of the trophic niche for each species was estimated using Levins index (Levins 1968), which reflects the use of resources by organisms, regardless of their relative availability in the habitat (Feinsinger et al. 1981). To compare the niche amplitude values between the species we divide the values into three levels: low (0-0. 33), middle (0.34-0.63) and high (0.64-1) (Hurlbert 1978). The index of relative importance (IRI) for each category of prey was also calculated (Biavati et al. 2004): IRI= F\%+N\%+F\%/3 where F\% is the frequency of occurrence, $\mathrm{N} \%$ the numeric percentage, and $\mathrm{V} \%$ the volumetric percentage.

The relationship between snout vent length (SVL) and jaw width (JW) of predators was explored through a random regression analysis in Ecosim Professional v1.2d software (Entsminger 2012), and a significant relationship was observed between the two variables $\left(r^{2}=0.96\right.$; $p<0.05)$. Therefore, to analyze the relationship between predator and prey size consumed variables were used predator jaw width (JW) and prey volume (PV). This relationship was explored through a random regression analysis in Ecosim Professional v1.2d software (Entsminger 2012).
The type of diet (specialist or generalist) and foraging strategies (active foraging or "sit-andwait") were defined considering the main food characteristics of each species, such as: niche breadth (Levins index- Levins 1968) the values were standardized from 0 to 1 to compare the niche amplitude between the species (Hurlbert 1978), diversity (Shannon-H 'index) and dietary equity (Pielou equity-J), number of consumed prey, average volume of prey per stomach, and morphometric relationships of the anurans with their prey (Toft 1981, Perry \& Pianka 1997, Vitt \& Caldwell 2014). In addition, the results were interpreted with the help of published literature on the diets composition, distribution and natural history of the species studied, or from congeners and field observations of habits and habitat use. Due to the variability of habits of the anurans studied and the ingested prey, it was difficult to estimate the availability of prey for all species, therefore, availability was assumed as the sum of the prey of the stomach contents of all species (Winemiller \& Pianka 1990, Vitt \& Caldwell 2009, Le et al. 2019).

Results do not meet statistical assumptions of normality and homocedasticity therefore we analyse spatial (sites) and temporal (seasons) differences in diet composition with a KruskallWallis nonparametric test. Differences in diets composition were explored using the PAST software package (Hammer et al. 2001).

The spatial and temporal trophic overlap of the anuran species was calculated, where the response variable in all cases was the proportion of each food item (expressed in proportions). We used the Pianka overlap index (Pianka 1973) of the Ecosim Professional v1.2d software (Entsminger 2012). We applied a recommended algorithm for this type of analysis, the randomization algorithm RA3, which retains the amplitude of the niche and reshuffled the zeros (Gotelli \& Ellison 2013, Lopes et al. 2015, Luiselli \& Amori 2016). All 
original values of the matrix were randomized 1000 times (Gotelli \& Entsminger 2005). With the results obtained, graphs were generated with frequencies of the overlapping values between every possible pairs of anuran species for each study site. These values were taken from the EcoSim output matrix for each site with Species $x$ Species overlap values, and divided into three categories: low $=0-32$, medium $=0.33-0.66$ and high $=0.67-1.00$. In this way, we could determine which overlapping values between species were more common per site. Interactions between pairs of species with the same overlap values were also plotted, allowing us to visualize the overlap between pairs of species, by sampling site and climatic season.

We identified trophic guilds based on the number of individuals of each prey item consumed and the habitats used by each anuran species (number of individuals per species). For this, we applied multidimensional non-metric scaling test (NMDS), following the proposal of Junker et al. (2013), in order to find similarities in the use of the resources, since it is a ordination technique for the analysis of proximity data (Arnau 1996, Guisande et al. 2011). This analysis was performed with PAST software (Hammer et al. 2001), using as Bray-Curtis similarity index for the ranking.

\section{RESULTS}

\section{General anurans diet}

Stomach contents of 19 anuran species with nocturnal habits were analysed (Table I). Of these, 438 types of prey were identified (species and morphospecies), including insects, arachnids, mollusks, centipedes (Chilopoda), isopods, malacostracans, oligochaetes, reptiles and amphibians (anurans) (Supplementary Material - Table SI). The amplitude of the trophic niche (Levins index) for all species was min=0.05 to $\max =0.98$ mean $=0,45$, with dominance of species with values less than 0.5 (Table I). Only Rhinella humboldti, Rhinella marina, Engystomops pustulosus, Pleurodema brachyops, Leptodactylus insularum, Leptodactylus fragilis, Boana pugnax and Scinax ruber presented significant relationship between predator JW with prey volume (Table I).

Most species were generalists in the consumption of prey (89.5\%) and some (21\%) showed a marked dominance of certain food items: Formicidae and Isoptera for Rhinella humboldti, Rhinella marina, and Engystomops pustulosus, and Hemiptera for Scarthyla vigilans (Table I). Only two species were classified as specialists: Elachistocleis pearsei and Elachistocleis panamensis, due to the consumption of ants and termites (Table I, Table SI). We recorded more species (11 species of families Bufonidae, Craugastoridae, Leptodactylidae and Microhylidae) with terrestrial than arboreal habits. Coleoptera was the most common prey in the diets (787 individuals and $41,799.7 \mathrm{~mm}^{3}$ in stomach contents), followed by Hymenoptera (mainly formicids, 6,088 individuals and $164.28 \mathrm{~mm}^{3}$ in stomach contents), Orthoptera, Isoptera and Araneae (Table I, Table SI).

\section{Diet diversity: spatial dinamics}

The sites were similar in composition of amphibian species $\left(K W_{6}=3.82, P=0.57\right)$ (Supplementary Material - Figure S1). The similarity between sites by type of consumption prey decreases when analyzing the diet at higher taxonomic resolution Figure S2). At the level of Order of consumed prey there weren't significant differences among the sites when analysing the contribution of food items in volume $\left(K W_{6}=3.86, P=0.5\right)$ and the number of preys ingested $\left(K W_{6}=2.74, P=0.7\right)$. Hymenoptera (mainly composed of Formicidae) was the order 
that most contributed in numerical terms at the sampling sites (> 58\%), except for site 4 , where Isoptera was the best represented (60.67\%). In volume, the order Coleoptera was the biggest contribution for sites 2 (74.02\%) and 5 (35.50\%).

Both in the taxonomic level of prey family and morphospecies there were significant differences among the sites when analysing the contribution of food items in volume $\left(K W_{6}\right.$ $=13.06, P=0.02$ and $K W_{6}=20.46, P=0.0010$, respectively) and in the number of ingested preys $\left(K W_{6}=14.24, P=0.01\right.$ and $K W_{6}=34.37, P=$ 0.0003 , respectively). Formicidae was the family that contributed the most in numerical terms at the sampling sites (52.8\%), except for site 4 , where Termitidae was the best represented. In volume, the family Cicadellidae was the biggest contribution at the sampling sites (28.1\%) especially in the sites 1 and 5 , in the site 2 Carabidae (31\%), site 3 Tettigonidae (15\%), site 4 Termitidae (20\%) and site 6 Formicidae (48\%) were the best represented.

\section{Diet diversity: seasonal dinamics}

When analysing the volumetric contribution made by each alimentary item at the taxonomic level of the Order, we observed that Orthoptera (24.8\%), Isoptera (18\%), Coleoptera (15.5\%) and Hymenoptera (13.8\%) contributed to the largest volume of anurans diet in the dry season. During early rainy season, Coleoptera (47.2\%), Hymenoptera (18.3\%) and Orthoptera (7.53\%) were the largest volume orders. In late rainy season, the first contributor was still the order Coleoptera $(26.70 \%)$ followed by Orthoptera (12\%) and Hymenoptera (11.1\%). There weren't significant differences between seasons when analysing the contribution of food items in volume ( $K W=3.85, P=0.14)$ and number of prey ingested $(K W=2.92, P=0.23)$.

The greatest richness of families ocurred in major rains ( 98 families) followed by minor rains
(93 families) and dry (78 families). However, there weren't significant differences between seasons when analysing the contribution of food items in volume ( $K W=2.58, P=0.27)$ and number of prey ingested $(K W=5.63, P=0.06)$. We observed that Formicidae y Termitidae were the families that most contributed to the number of individuals at all seasons. Termitidae (18\%), Acrididae (15\%) and Formicidae (13\%) contributed to the largest volume to the diet of anurans in the dry season. During early rainy season, Carabidae (22\%), Formicidae (15\%) and Scarabaeidae (9\%) were the largest volume families. In late rainy season, the first contributor was still the family Cicadellidae (62\%) followed by Formicidae (4\%) and Scarabaeidae (4\%).

At the regional level seasons showed differences in the richness of species / morphospecies of the consumed prey. There were significant differences between seasons when analysing the contribution of food items in volume ( $K W=9.03, P=0.01)$ and number of prey ingested ( $K W=11.82, P=0.006)$. In the dry season, the lowest number of food items (193 prey types) was recorded, while during the minor rains, the maximum number of prey categories consumed (237 prey types) was observed, followed by major rains (223 prey types). This pattern is maintained at the local level, except in Site 3 where the greatest contribution was made in the rainy season and the smallest in the rainy season (Figure S3).

\section{Spatial diet overlap}

Trophic overlap, calculated with prey at order level, was low (0-0.33), and data randomization resulted in significant differences between the observed niche overlap and the randomly expected niche overlap (interactions $=1000$ ) (Table II). For all cases, variance values were significantly higher than expected by chance, except for Site 6 (Table II). Sites 6, 1 and 4 
Table II. Overlapping values (Pianka index) and variance by site and season between anurans of areas of tropical dry forest of the Caribbean Colombia region. $\mathrm{X}_{\mathrm{OBS}}=$ Observed Mean, $\mathrm{X}_{\mathrm{SIM}}=$ Simulated Mean, DS = Standard Deviation (equals the square root of the variance), $\operatorname{Var}_{\text {obs }}=$ Observed variance, $\operatorname{Var}_{\text {sim }}=$ Simulated Variance. $P=$ significance level.

\begin{tabular}{|c|c|c|c|c|c|c|}
\hline & $\begin{array}{l}\underline{X}_{\text {OBS }} \\
\pm \text { DS }\end{array}$ & $\begin{array}{l}\underline{X}_{\mathrm{SIM}} \\
\pm \text { DS }\end{array}$ & p & Var $_{\text {obs }}$ & Var $_{\text {sim }}$ & p \\
\hline Site 1 & $0.27 \pm 0.26$ & $0.14+0.024$ & 0.001 & 0.07 & 0.04 & 0.01 \\
\hline Site 2 & $0.38 \pm 0.3$ & $0.12 \pm 0.019$ & $<0.05$ & 0.09 & 0.04 & $<0.05$ \\
\hline Site 3 & $0.30 \pm 0.28$ & $0.14 \pm 0.022$ & $<0.05$ & 0.08 & 0.04 & $<0.05$ \\
\hline Site 4 & $0.22 \pm 0.3$ & $0.12 \pm 0.026$ & 0.002 & 0.09 & 0.04 & 0.006 \\
\hline Site 5 & $0.33 \pm 0.26$ & $0.14+0.018$ & $<0.05$ & 0.07 & 0.03 & $<0.05$ \\
\hline Site 6 & $0.21 \pm 0.22$ & $0.14 \pm 0.021$ & 0.003 & 0.05 & 0.04 & 0.21 \\
\hline Dry & $0.39 \pm 0.26$ & $0.16 \pm 0.017$ & $<0.05$ & 0.07 & 0.04 & 0.002 \\
\hline Minor rains & $0.24 \pm 0.24$ & $0.11 \pm 0.015$ & $<0.05$ & 0.06 & 0.03 & 0.003 \\
\hline Major rains & $0.36 \pm 0.07$ & $0.16 \pm 0.015$ & $<0.05$ & 0.07 & 0.03 & $<0.05$ \\
\hline
\end{tabular}

presented the lowest niche overlap values among species of anurans. At site 2, we observed the highest frequency of high niche overlap values (0.66-1), followed by sites 3 and 5 (Fig. 2).

Analyzing the overlapping of species pairs by site we see that at site $2, R$. marina presented a higher number of high dietary niche overlaps (6 pairs of high overlaps) with other species, followed by L. insularum, L. fragilis and L. fuscus, which presented high values of overlap with five species each. Rhinella marina was also the most overlapping species with others (5 pairs of high overlaps) at site 3 , followed by S. ruber, $P$. brachyops and L. insularum, which overlapped with high values with four other species (Fig. 2). Pleurodema brachyops presented the most pairs of high overlap with other species at three of the sampling sites. At sites 1 and $6, P$. brachyops was the only species that formed higher pairs of high overlap between species, interacting with three species at the first site and with two at site 6 . At site 4, P. brachyops was also the most overlapping species, forming pairs with four other species, followed by $R$. humboldti, L. poecilochilus and L. insularum, which overlapped with three species each (Fig. 2). In site 5, L. poecilochilus formed high overlap pairs with five other species, followed by Boana pugnax and L. insularum, which presented high values of overlap with four other species each (Fig. 2).

\section{Seasonal diet overlap}

The highest number of species pairs with high overlap values (calculated at prey order level) were observed in the dry season. Rhinella humboldti, Craugastor raniformis, E. pustulosus, L. insularum, E. pearsei and E. panamensisformed highly overlapping pairs with six other species each. In minor rains, the number of overlapping species decreased. Pleurodema brachyops formed the most highly overlapping pairs with five other species, followed by R. humboldti, Dendropsophus microcephalus, L. fragilis, $L$. fuscus and E. panamensis, which formed highly overlapping pairs with three more species each. In major rains, the pairs of species with high trophic overlap increased. Leptodactylus fragilis overlapped with nine other species, followed by $P$. brachyops and L. insularum with six species 


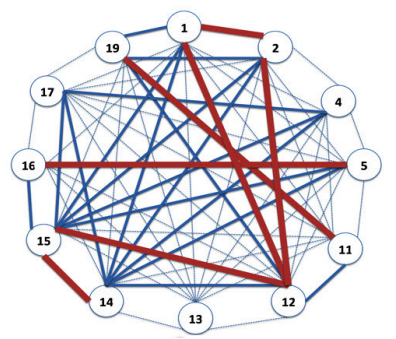

Site 1
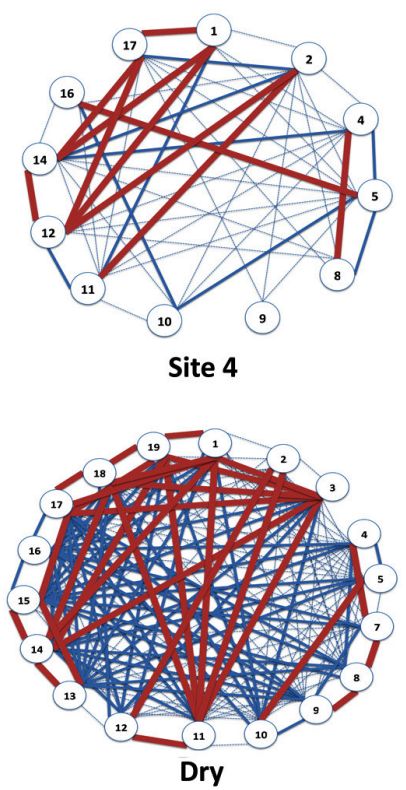

Dry

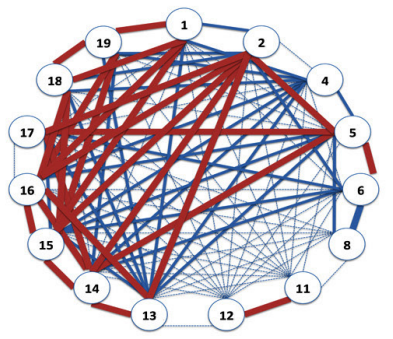

Site 2

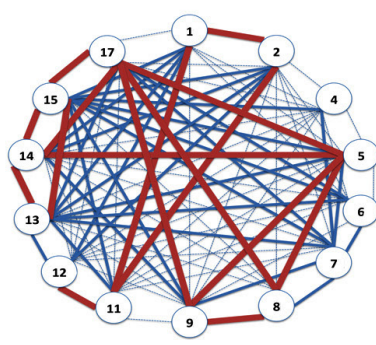

Site 5

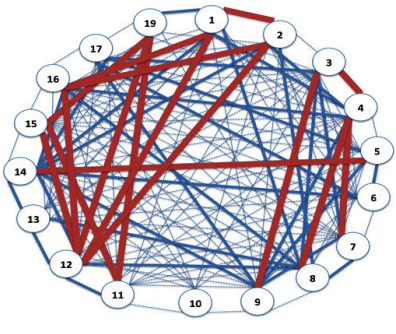

Minor rains

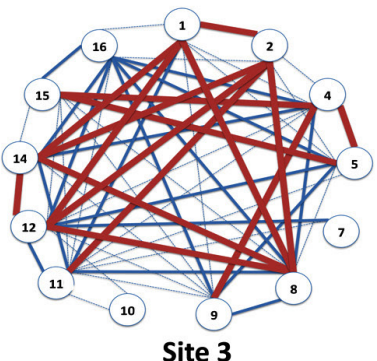

Site 3

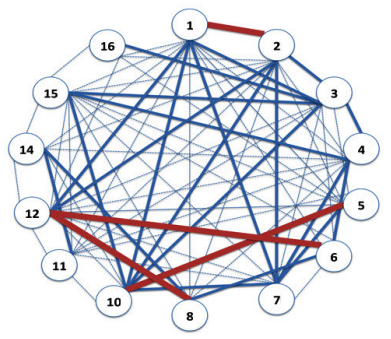

Site 6

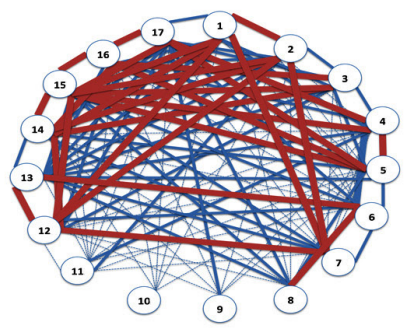

Major rains
Figure 2. Trophic overlap (Pianka Index) between pairs of anuran species for each study site and climatic season in tropical dry forest areas of the Colombian Caribbean. Line thickness represents the value of the overlap. The numbers correspond to the anuran species listed in Table I.

$-0-0.32-0.33-0.65-0.66-1$

each. Finally, R. humboldti, R. marina and $L$. fuscus formed pairs with five species each (Fig. 2).

\section{Anurans trophic guilds}

Two potential guilds of anurans were identified, according to diet structure and habitat use (Table SII): Ground foraging anurans consuming Formicidae and Isoptera, composed of $E$. pearsei, E. panamensis, R. humboldti, R. marina, P. brachyops and E. pustulosus, and Arboreal anuran, 'sit-and-wait' consumers, mainly of arachnids, composed of S. rostratus, S. ruber and D. microcephalus. The NMDS system proved to be effective in detecting data pooling (Stress
$=0.17$ ). Axes 1 and 2 explained $71 \%$ of the data variation. Ten anurans species (52.6\%) did not show tendencies to be grouped in trophic guilds: C. raniformis, B. pugnax, L. insularum, L. fragilis, L. fuscus, L. poecilochilus, Phyllomedusa venusta, Pseudopaludicola pusilla, Scarthyla vigilans and Trachycepallus typhonius. These species showed different patterns in their feeding habits and, therefore, it was not possible to locate them in a defined trophic guild (Fig. 3). 


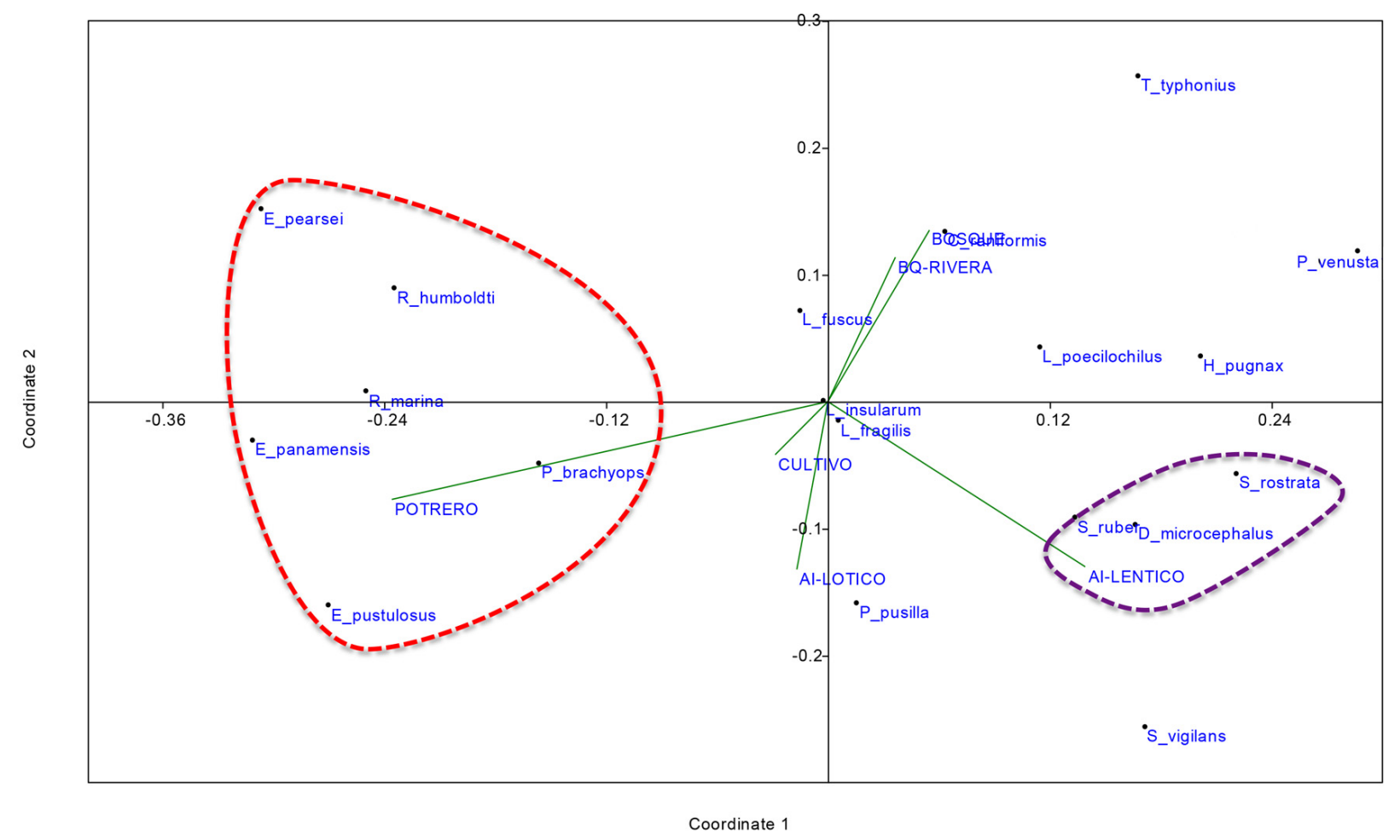

Figure 3. Trophic guilds of anurans in areas of tropical dry forest of the Colombian Carribbean, based on diet and habitat use. The areas enclosed in dotted lines represent the probable trophic guilds.

\section{DISCUSSION}

\section{Anurans diet: generalities in lowlands}

In this study, a large number of food items were observed, reflecting both high viability and food variability, as well as the prevalence of frog species with generalist diets. Although tropical dry forest anurans are mostly generalist, three species showed dominance or specialization in the consumption of certain types of prey. In turn, two species are active foragers and one species was classified as "sit-and-wait". We found that the only species with a specialized diet were the microhylidae E. panamensis and E. pearsei in the consumption of ants and termites. This specialization in the diet has been widely reported for these and other species of microhylids (e.g. Parmelee 1999, Van Sluys et al. 2006, López et al. 2007). However, we also observed species that exhibited preferential consumption of a certain type of prey; such is the case of the two Rhinella species that consumed a high number of ants. These results coincide with previous studies in numerous species of bufonids (e.g. Clarke 1974, Duré \& Kehr 1996, Isacch \& Barg 2002, Isaacs \& Hoyos 2010). Engystomops pustulosus preferentially consumed termites and ants, a behaviour that was previously recorded for this species (González-Duran et al. 2012), and is repeated in other congeners (e.g. Parmelee 1999, Santana \& Junca 2007, Narváez \& Ron 2013). Finally, S. vigilans is a special case, being a "Sit-andWait" predator (Fonseca-Pérez et al. 2017), with tendency to consume Hemiptera.

\section{Spatial-seasonal diets dynamics}

Our results show that at the Order level, the overlapping is evident but not at higher levels of taxonomic resolution such as families or 
morphospecie. This classification reveals broadscale trophic patterns not detectable when working at a more detailed prey level, such as species or morphospecies (Piatti \& Souza 2011, Fonseca-Pérez et al. 2017). At a spatial scale, the sites were dissimilar in composition and abundance of species and morphospecies of prey. It is important to note that differences in habitat use by anuran species affect the type of prey consumed (Toft 1981, Parmelee 1999, MuñozGuerrero et al. 2007, Duré et al. 2009, Isaacs \& Hoyos 2010), so that dissimilarities in their diet, at the level of species and morphospecies, could result from the variety of habitats they occupy, and also can be a result of prey availability between seasons and sites (Michelin et al. 2020). Active forager anurans with generalist diets capture their prey according to their abundance at each site (Vitt \& Caldwell 2014). Therefore, the differences mentioned above could be reflected in their diets. This could lead to different prey being consumed in different proportions in the sampled areas and seasons (Vitt \& Caldwell 2014).

The temporal diet structure is dynamic and dependent on the climatic variations of the study area. Thus, in the dry season, the number of prey (species and morphospecies) was lower than in the wet season, which could can influence directly on similarity between the diets of the different species. When rains arrived, there was an increase in most forms of tropical dry forest life and this was also observed by an increase in richness of prey consumed. Therefore, the climatic variation of the tropical dry forest influences the species richness of the different arthropod orders that are available to the anuran species in this environment (Whitfield \& Donelly 2006, Palacios-Vargas et al. 2007).

\section{Anurans trophic overlap in lowlands}

Regarding the analysis of trophic overlap, in general, we observed a higher overlap and variance than expected by chance. The overlap in the diets of these species could indicate that they share several food resources, but not necessarily that they are competing. Albrech \& Gotelli (2001) found that there was no divergence of niches under selective pressure, which could lead to a high availability of resources or the existence of "young" assemblages. In all sites, there were always more species pairs with low niche overlap values. Although there were high values of niche overlap among some pairs of species, they used different habitats, which may indicate a process of convergence when consuming prey that are abundant in the system and, therefore, that are consumed in different places and times (Gotelli \& Entsminger 2005). On the other hand, high variance values could indicate a community structure with defined guilds, in that some species are very similar in the use of resources, but dissimilar with respect to other species of the same community (Gotelli \& Entsminger 2005).

When analysing the diets at different seasons, in all cases, the observed niche overlap was significantly higher than expected by chance. This contrast the hypothesis of Toft (1980b), who argues that species in times of scarcity try to avoid competition to optimize the available resources. In this study, we observed more species pairs with high overlap values in the dry season (shortage). At the beginning of the rains, however, the lowest number of pairs of overlapping species was registered. Therefore, one might think that the dynamics of the trophic interrelations of the anuran assemblage depend on the climatic variation and that modify the food supply of the tropical dry forest, because rains increase the abundance of insects, 
especially from the end of the dry season to the start of the rainy season (Pereira et al. 2011).

\section{Anurans trophic guilds in lowlands}

According to the trophic patterns observed for the anuran species of this study, it can be concluded that some of them form two distinct trophic guilds, highly differentiable in the ecology of the species that comprise it. The general patterns of the diets, analyzing the prey consumed at the order level, are conserved in the species despite the variations between localities (Almeida et al. 2019, Silva \& RossaFeres 2010). The species within a guild share a similar diet structure and some similarities in the use of space, time of activity, morphology and foraging strategy. The latter could confirm that resources can be used in a similar way by some species (Root 1967, Hawkins \& MacMahon 1989).

The first identified guild is composed of "foragers consumers of formicides and isoptera." It consists of six species that move in a horizontal plane, at ground level. They were commonly observed in open areas, mainly in pastures. They use, preferably, the active search for obtaining preys and are specialists in the consumption of termites and ants during all climatic periods, making it a stable guild in tropical dry forest. This guild has been proposed in other works for neotropical environments, conserving a similar species composition or with phylogenetic closeness (Toft 1980a, Parmelee 1999, Wells 2007).

Other clearly defined guild corresponded to the "Arboreal 'sit-and-wait' consumers, mainly of arachnids", composed of species that have the ability to move in the horizontal and vertical planes, commonly associated with the vegetation of bodies of water. Although their diets are generalist, all of them show a high consumption of arachnids. Although predators with a sit-and-wait strategy do not specialize in a particular prey type (Toft 1981, Perry \& Pianka 1997), it is likely that the abundance and behaviour of arachnids in the environment, generates a marked increase in their consumption. This diet composition is similar to that found in these same species and congeners in other studies (Duré 1999, Muñoz-Guerrero et al. 2007, Teixeira \& Rödder 2007).

A considerable number of species were not clearly grouped in the analysis of the community trophic structure. This could result from the fact that none of them shared identifiable characteristics or food patterns that allowed them to be included in any particular guild. Among them, some are active forager and other sit-and-wait, but all showed a general diet whose composition could be closely related to the high variability and abundance of preys offered by these areas. The latter could allow the trophic segregation observed between these species.

The guilds defined may be related to the foraging patterns of predators which is dependent on to the availability of prey (at the order (evel) in tropical dry forests of Colombia (Escobar 1997, Armbrecht \& Ulloa-Chacón 1999, Camero et al. 2005). Most species with active forager habits formed guilds and this could be related to the active search habit, which could allow specialization or dominance for a particular type of prey. The study of guilds or ecologically similar groups has been used to understand the structure of communities (Williams \& Hero 1998). When a community presents this type of modules or guilds, it can be inferred that the species that integrate each module interact more with each other than with species of other guilds (Amarasekare 2008, Benítez et al. 2014). Accordingly, any disturbance that influences the probability of survival of the species within the guild would not drastically affect the probability of survival of the community. This structure 
allows greater stability in time and in the face of disturbance processes, which would explain the high capacity of these communities to withstand the natural habitat loss of the tropical dry forest in Colombia (Pizano \& García 2014).

The studied species of anurans used both the forests and disturbed areas, were active at the same time of night, had mostly terrestrial habits, and could be grouped by the consumption of broad-scale prey groups (Order). However, the diversity of species within these broadscale groups of prey generated variation in the diet, possibly decreasing competition among predator species, and allowing trophic niche segregation. Therefore, it is likely that species of tropical dry forest anurans in the Colombian Caribbean partitioning trophic resources at the level of prey species and morphospecies, as a mechanism of coexistence.

\section{Acknowledgments}

We thank to the Departamento Administrativo de Ciencia, Tecnología e Innovación de Colombia, Observatorio del Caribe Colombiano and Universidad del Atlántico (Biology department- Biological Collection, collecting permission 949) for the Scholarships: Researchers and Innovative Young People and Doctoral training Francisco Jose de Caldas "Generación del Bicentenario", ScienceBiology postgrad program and Biology Department from the Universidad Nacional de Colombia and Centro de Ecología Aplicada del Litoral- Consejo Nacional de Investigaciones Científicas y Técnicas (CECOAL-CONICET), Corrientes, Argentina, for the academic and logistic support. We thank Cerrejón Ltd. RNSC Campoalegre, Tití Project, George Dahl Foundation, the Atlantic Coast Corporaciones Autónomas Regionales and the people of the region for the logistic support, relevant permits and authorizations in the sampling sites. We thank the entomologists who identified prey items. Finally, we thank M. C. Franco for the cartographic and image edition, G. Huidobro, A. Gonzalez, D. Duran and P. Saravia for language support and E. Scheafer for image support. Finally, we thank to the editor and reviewers for the helpful suggestions that improved this manuscript.

\section{REFERENCES}

ADAMS D. 2007. Organization of Plethodon Salamander Communities. Guild-Based Community Assembly. Ecology 88: 1292-1299.

ALBRECH M \& GOTELLI N. 2001. Spatial and temporal niche partitioning in grassland ants. Oecol 126: 134-141.

ALMEIDA B, SANTOS R, DOS SANTOS T, DE SOUZA M \& MENIN M. 2019. Diet of five anuran species in a forest remnant in eastern Acre state, Brazilian Amazonia. Herpetol Notes 12: $945-952$.

AMARASEKARE P. 2008. Spatial Dynamics of Foodwebs. Annu Rev Ecol Evol Syst 39: 479-500.

ANGULO A, RUEDA-ALMONACID J, RODRÍGUEZ-MAHECHA J \& LA MARCA E. 2006. Técnicas de Inventario y Monitoreo para los Anfibios de la Región Tropical Andina. Bogotá: Panamericana Formas e Impresos S.A., 299 p.

ARMBRECHT I \& ULLOA-CHACÓN P. 1999. Rareza y Diversidad de Hormigas en Fragmentos de Bosque Seco Colombianos y sus Matrices. Biotropica 3: 646-653.

ARNAU J. 1996. Métodos y técnicas avanzadas de análisis de datos en ciencias del comportamiento. Barcelona: Editorial Universitat de Barcelona, 366 p.

BENGTSSON J. 1998. Which species? What kind of diversity? Which ecosystem function? Some problems in studies of relations between biodiversity and ecosystem function. Appl Soil Ecol 10: 191-199.

BENITEZ M, MIRAMONTES O \& VALIENTE-BANUET A. 2014. Frontiers in Ecology, Evolution and Complexity. Mexico D.F.: EditoraC3, 283 p.

BIAVATI G, WIEDERHECKER H \& COLLI G. 2004. Diet of Epipedobates flavopictus (Anura: Dendrobatidae) in a Neotropical Savanna. J Herpetol 38: 510-518.

BLANCO-TORRES A, BARUFFOL M, ACOSTA GALVIS A \& NUÑEZ N. 2019. Rasgos funcionales de anfibios de Colombia. Bogotá D. C.: Instituto Alexander von HumboldtColciencias, $69 \mathrm{p}$.

BLANCO-TORRES A, DURÉ MI, BONILLA MA \& CAGNOLO L. 2020. Predator-Prey Interactions in Tropical Dry Forest Anurans of the Colombian Caribbean: A Functional Approach. Biotropica 52: 730-737.

BRICEÑO-MÉNDEZ M, NARANJO E, PÉREZ-IRINEO G, CONTRERASPERERA Y, SANDOVAL-SERÉS E \& HIDALGOMIHART MG. 2017. Richness and trophic guilds of carnivorous mammals in ejido Nuevo Becal, Calakmul, Campeche, Mexico. Therya 8: $145-150$. 
BRUSSAARD L. 1998. Soil fauna, guilds, functional groups and ecosystem processes. Appl Soil Ecol 9: 123-135.

CAMERO-R E, DÍAZ J, SALINAS A, SALINAS A, TÉLLEZ L \& AGUDELO D. 2005. Estudio de la artropofauna asociada a suelos de dos tipos de ecosistemas en la cuenca del río Cauca Colombia. Acta Biol Colomb 10: 35-44.

CERON K, OLIVEIRA-SANTOS LGR, SOUZA CS, MESQUITA DO, CALDAS FL, ARAUJO AC \& SANTANA DJ. 2019. Global patterns in anuran-prey networks: structure mediated by latitude. Oikos 128: 1537-1548.

CLARKE R. 1974. Food Habits of Toads. Genus Bufo (Amphibia: Bufonidae). Am Midl Nat 91: 140-147.

CLAVEL J, JULLIARD R \& DEVICTOR V. 2011. Worldwide decline of specialist species: toward a global functional homogenization?. Front Ecol Environ 9: 222-228.

CRUMP ML \& SCOTT NJ. 1994. Visual encounter surveys. In: Heyer WR et al. (Eds), Measuring and Monitoring Biological Diversity Standard Methods for Amphibians, Washington DC.: Smithsonian Institution Press, p. 84-92.

DUNHAM AE. 1983. Realized niche overlap, resource abundance and intensity of interspecific competition. In: Huey RD et al. (Eds), Lizards Ecology, Cambridge: Harvard University Press, p. 261-280.

DURÉ M. 1999. Interrelaciones en los nichos tróficos de dos especies sintópicas de la familia hylidae (anura) en un área subtropical de Argentina. Cuadernos Herpetol 13: 11-18.

DURÉ M \& KEHR A. 1996. Bufo paracnemis (kururu Guazu. Sapo Buey. Sapo Rococo). DIET. Herpetol Rev 27: 138.

DURÉ MI, KEHR A \& SCHAEFER E. 2009. Niche overlap and resource partitioning among five sympatric bufonids (Anura, Bufonidae) from northeastern Argentina. Phyllomedusa 8: 27-39.

ENTSMINGER GL. 2012. EcoSim Prefessional: Null modelling software for ecologists. Available from: http://www. garyentsminger.com/ecosim/index.htm.

ESCOBAR F. 1997. Estudio de la comunidad de coleópteros coprófagos (Scarabaeidae) en un remanente de bosque seco al norte del Tolima, Colombia. Caldasia 19: 419-430.

FEINSINGER P, SPEARS E \& POOLE R. 1981. A simple measure of niche breadth. Ecology 62: 27-32.

FERNANDEZ F. 2003. Introducción a las Hormigas de la región Neotropical. Bogotá: Instituto de Investigación de Recursos Biológicos Alexander von Humboldt, 404 p.
FONSECA-PÉREZ KA, MOLINA C \& TÁRANO Z. 2017. Diet of Dendropsophus microcephalus and Scarthyla vigilans (Anura: Hylidae) at a locality in north-western Venezuela with notes on microhabitat occupation. Pap Avulsos Zool 57: $93-104$.

GARCÍA-ROBLEDO C, KUPREWICZ EK, BAER CS, CLIFTON E, HERNÁNDEZ GG \& WAGNER DL. 2020. The Erwin equation of biodiversity: From little steps to quantum leaps in the discovery of tropical insect diversity. Biotropica 52: 1-8.

GONZÁLEZ-DURAN G, GUTIÉRREZ-CÁRDENAS P \& ESCOBAR LASSO S. 2012. Physalaemus pustulosus (Tungara Frog). DIET. Herpetol Rev 43: 124.

GOTELLI NJ \& ELLISON AM. 2013. EcoSimR, Version 1.00. Available from: http://www.uvm.edu/ ngotelli/ Ecosim/Ecosim.html.

GOTELLI N \& ENTSMINGER G. 2005. EcoSim: Null models software for ecology. Version 7.0. Available from: <http:// homepages.together. net/ gentsmin/ecosim.htm>.

GUISANDE GONZÁLEZ C, VAAMONDE LISTE A \& BARREIRO FELPETO A. 2011. Tratamiento de datos con R, Statistica y SPSS. Madrid: Ediciones Díaz de Santos, 978 p.

HAMMER $\varnothing$, HARPER D \& RYAN P. 2001. PAST: Paleontological Statistics Software Package for Education and Data Analysis. Palaeontol Electron 4: 1-9.

HAWKINS CH \& MACMAHON J. 1989. Guilds: The multiple meanings of a concept. Ann Rev Entomol 34: 423-451.

HURLBERT S. 1978. The Measurement of Niche Overlap and Some Relatives. Ecology 59: 67-77.

ISAACS P \& HOYOS JM. 2010. Diet of the Cane Toad in Different Vegetation Covers in the Productive Systems of the Colombian Coffee Region. S Am J Herpetol 5: 45-50.

ISACCH J \& BARG M. 2002. Are bufonid toads specialized ant-feeders? A case test from Argentinian flooding pampa. J Nat Hist 36: 2005-2012.

JUNKER R, BLÜTHGEN N, BREHM T, BINKENSTEIN J, PAULUS J \& SCHAEFER HM. 2013. Specialization on traits as basis for the niche-breadth of flower visitors and as structuring mechanism of ecological networks. Funct Ecol 27: 329-341.

LE DT, ROWLEY J, TRAN DTA, VO TN \& HOANG HD. 2019. Diet Composition and Overlap in a Montane Frog Community in Vietnam. Herpetol Conserv Biol 13: 205-215.

LEVINS R. 1968. Evolution in Changing Environments: Some Theoretical Explorations. Princeton: Princeton University Press, 132 p.

LOPES GN, SOUZA-FILHO MF, GOTELLI NJ, LEMOS L, GODOY W \& ZUCCHI R. 2015. Temporal Overlap and Co-Occurrence in a 
Guild of Sub-Tropical Tephritid Fruit Flies. PLoS ONE 10: e0132124.

LÓPEZ J, GHIRARDI R, SCARABOTTI P \& MEDRANO M. 2007. Feeding ecology of Elachistocleis bicolor in a riparian locality of the middle Paraná River. Herpetol J 17: 48-53.

LUISELLI L \& AMORI G. 2016. Diet. In: Dodd CK Jr. (Ed), Reptile Ecology and Conservation a handbook of techniques, Oxford: Oxford University Press, p. 97-109.

MAGURRAN AE. 2004. Measuring Biological Diversity. London: Blackwell Publishing Company, 215 p.

MARTÍNEZ RAMOS M. 2008. Grupos funcionales. In: Soberón J et al. (Eds), Capital natural de México, Vol. I. Conocimiento actual de la biodiversidad, Mexico D.F.: Conabio, p. 365-412.

MICHELIN G, CERON K \& SANTANA DJ. 2020. Prey availability influences the diet of Scinax fuscomarginatus in a Cerrado area, Central Brazil. Anim Biodivers Conserv 43: 169-175.

MORIN P. 1983. Predation, Competition, and the Composition of Larval Anuran Guilds. Ecol Monogr 53: 119-138.

MUÑOZ-GUERRERO J, SERRANO V \& RAMÍREZ-PINILLA M. 2007. Uso de microhábitat, dieta y tiempo de actividad en cuatro especies simpátricas de ranas hílidas neotropicales (Anura: Hylidae). Caldasia 29: 413-425.

NARVÁEZ AE \& RON SR. 2013. Feeding Habits of Engystomops pustulatus Anura. Leptodactylidae in Western Ecuador. S Am J Herpetol 8: 161-167.

PALACIOS-VARGAS J, CASTAÑO-MENESES G, GÓMEZ-ANAYA J, MARTÍNEZ-YRIZAR A, MEJÍA-RECAMIER B \& MARTÍNEZ-SÁNCHEZ J. 2007. Litter and soil arthropods diversity and density in a tropical dry forest ecosystem in Western México. Biodivers Conserv 16: 3703-3717.

PARKER K, PARKER A \& VALE T. 2001. Vertebrate Feeding Guilds in California's Sierra Nevada. Relations to Environmental Condition and Change in Spatial Scale. Ann Assoc Am Geogr 91: 245-262.

PARMELEE J. 1999. Trophic ecology of a tropical anuran assemblage. Sci Pap Univ Kansas Nat Hist Mus 11: 1-59.

PEREIRA NA, FRIZZAS MR \& DE OLIVEIRA CM. 2011. Seasonality in insect abundance in the "Cerrado" of Goiás State, Brazil. Rev Bras Entomol 55: 79-87.

PERRY G \& PIANKA E. 1997. Animal foraging. past, present and future. Trends Ecol Evol 12: 360-364.

PIANKA E. 1973. The structure of lizard communities. Annu Rev Ecol Syst 4: 53-74.
PIATTI L \& SOUZA F. 2011. Diet and resource partitioning among anurans in irrigated rice fields in Pantanal, Brazil. Braz J Biol 71: 653-661.

PIZANO C \& GARCíA H. 2014. El Bosque Seco Tropical en Colombia. Bogotá D.C: Instituto de Investigación de Recursos Biológicos Alexander von Humboldt, 354 p.

RANGEL-CH J, LOWY-C P \& SANCHEZ-C H. 1995. Región Caribe. In: Rangel-Ch JO (Ed), Colombia Diversidad Biótica I, Bogotá D.C.: Instituto de Ciencias Naturales-Universidad Nacional de Colombia-Inderena, p. 217-232.

RANVESTEL AW, LIPS K, PRINGLE C, WHILES M \& BIXBY R. 2004. Neotropical tadpoles influence stream benthos: evidence for the ecological consequences of decline in amphibian populations. Freshw Biol 49: 274-285.

ROOT R. 1967. The niche exploitation pattern of the bluegrey gnatcatcher. Ecol Monogr 37: 317-350.

SANTANA AS \& JUNCÁ F. 2007. Diet of Physalaemus cf. cicada (Leptodactylidae) and Bufo granulosus (Bufonidae) in a semideciduous forest. Braz J Biol 67: 125-131.

SILVA FR \& ROSSA-FERES DC. 2010. Diet of anurans captured in forest remnants in southeastern Brazil. Rev Esp Herpetol 24: 5-17.

SIMBERLOFF D \& DAYAN T. 1991. The Guild Concept and the Structure of Ecological Communities. Annu Rev Ecol Syst 22: $115-143$.

STUART SN, HOFFMANN M, CHANSON JS, COX NA, BERRIDGE RJ, RAMANI P \& YOUNG BE. 2008. Threatened Amphibians of the World. Barcelona: Lynx Edicions, Arlington: IUCN, Gland and Conservation International, 776 p.

TEIXEIRA R \& RÖDDER D. 2007. Diet, foraging strategy and reproduction of Scinax argyreornatus (MirandaRibeiro, 1926) from a mountainous region of the Atlantic rainforest in southeastern Brazil (Anura: Hylidae). Herpetozoa 19: 161-173.

TOFT C. 1980a. Feeding ecology of thirteen syntopic species of anurans in a seasonal tropical environment. Oecologia 45: 131-141.

TOFT C. 1980b. Seasonal variation in populations of Panamanian litters frogs and their prey. a comparison of wetter and drier sites. Oecologia 47: 34-38.

TOFT C. 1981. Feeding Ecology of Panamanian litter anurans. Patterns in diet and foraging mode. J Herpetol 15: $139-144$.

TRIPLEHORN C \& JOHNSON N. 2005. Borror \& DeLong'S introduction to the study of insects. Belmont: Thomson Brooks/Cole, 881 p. 
VAN SLUYS M, SCHITTINI GM, MARRA RV, AZEVEDO ARM, VICENTE J \& VRCIBRADIC D. 2006. Body size, diet and endoparasites of the microhylid frog Chiasmocleis capixaba in an Atlantic Forest areaof southern Bahiastate, Brazil. Braz J Biol 66: 167-173.

VARGAS-SALINAS F, MUÑOZ-AVILA JA \& MORALES-PUENTES ME. 2019. Biología de los anfibios y reptiles en el bosque seco tropical del norte de Colombia. Tunja: Editorial UPTC, 484 p.

VITT L \& CALDWELL J. 2009. Herpetology An Introductory Biology of Amphibians and Reptiles, $3^{\text {rd }}$ edition. San Diego: Elsevier Inc, 713 p.

VITT L \& CALDWELL J. 2014. Herpetology An Introductory Biology of Amphibians and Reptiles, $4^{\text {th }}$ edition. San Diego: Academic Press, 749 p.

WELLS KD. 2007. The ecology and behaviour of amphibians. Chicago: University Chicago Press, 1162 p.

WHITFIELD M \& DONELLY M. 2006. Ontogenetic and seasonal variation in the diets of a Costa Rican leaf-litter herpetofauna. J Trop Ecol 22: 409-417.

WILLIAMS S \& HERO J. 1998. Rainforest Frogs of the Australian Wet Tropics. Guild Classification and the Ecological Similarity of Declining Species. Proc Biol Sci 265: 597-602.

WINEMILLER KO \& PIANKA ER. 1990. Organization in natural assemblages of desert lizards and tropical fishes. Ecol Monogr 60: 27-55.

WOLFF M. 2006. Insectos de Colombia. Medellín: Multimpresos Ltda, $460 \mathrm{p}$.

\section{SUPPLEMENTARY MATERIAL}

Table SI.

Table SII.

Figure S1

Figure S2

Figure S3

\section{How to cite}

BLANCO-TORRES A, MARTA DURÉ M \& BONILLA MA. 2021. Anurans trophic dynamic and guild structure in tropical dry forests of the Caribbean region of Colombia. An Acad Bras Cienc 93: e20201022. DOI 10.1590/00013765202120201022.

Manuscript received on June 30, 2020;

accepted for publication on November 30, 2020

\section{ARGELINA BLANCO-TORRES ${ }^{1,2}$}

https://orcid.org/0000-0002-6961-6845

\section{MARTA DURÉ $\dot{3}^{3}$}

https://orcid.org/0000-0002-7037-162X

\section{MARÍA ARGENIS BONILLA ${ }^{2}$}

https://orcid.org/0000-0001-6944-613X

${ }^{1}$ Universidad de la Costa, Departamento de Ciencias Naturales y Exactas, Calle 58 No.55-66, C.P 080002, Barranquilla, Colombia ${ }^{2}$ Grupo de Investigación en Biología de Organismos Tropicales, Departamento de Biología, (edificio 421), Laboratory 224, Facultad de Ciencias, Universidad Nacional de Colombia, Sede Bogotá, Avenida 30 No. 45-03, Bogotá, Colombia

${ }^{3}$ Centro de Ecología Aplicada del Litoral (CECOAL), Consejo Nacional de Investigaciones Científicas y Técnicas (CONICET), Ruta 5, Km 2.5, C.P 3400, Corrientes, Argentina

\section{Correspondence to: Argelina Blanco-Torres}

E-mail:ablanco21@cuc.edu.co

\section{Author contributions}

$A B T$ and $M A B$ conceived the ideas; $A B T, M D$ and $M A B$ designed methodology; $A B$ collected the data; $A B, M D$ and $M A B$ analysed the data; $A B, M D$ and $M A B$ led the writing of the manuscript. All authors contributed critically to the drafts and gave final approval for publication.

\section{(cc) BY}

